\title{
VIBRATION ANALYSIS OF THE DRIVETRAIN IN DEPENDENCE ON THE TYPE OF GEARBOX SUSPENSION BUSHING
}

\author{
STRUZ Jiri ${ }^{1 *}$, HRUZIK Lukas ${ }^{1}$, HAVLIK Jiri ${ }^{1}$ \\ ${ }^{I}$ VSB - Technical University of Ostrava, Faculty of Mechanical Engineering, Institute of Machine parts and \\ Mechanisms, 17. listopadu 2172/15, 70800 Ostrava-Poruba, Czech Republic, e-mail: jiri.struz@vsb.cz.
}

\begin{abstract}
In the vast majority of technical applications, there is a necessity to transmit the torque from drive to driven machine together with the demand to overcome great distance between given devices. One of the solutions of this problem is the use of a cardan shaft. Operations of connecting shaft and drivetrain are accompanied by oscillations negatively influencing the driver comfort. Main subject of this article is the measurement of vibrations on different parts of a heavy truck and its evaluation by FFT analysis. Measurements are performed with two kinds of suspension bushing which are compared with to each other. Based on the previous measuring, influence of cardan shaft length was also investigated. First of all, dependency on the length of the cardan shaft on deflection angles for $\mathrm{V}$ arrangement was evaluated by analytical method. The theoretical introduction is followed by research of eigen frequency depending on the length of the cardan shaft. The results obtained by modal analysis in FEM are verified by experimental modal analysis [1].
\end{abstract}

KEYWORDS: vibration, length of cardan shaft, eigen frequencies (natural frequencies), square suspension bushing, cylindrical suspension bushing, drivetrain

\section{Introduction}

This research responds to increasing demands of heavy truck's drivers on ergonomics during their driving. Drivers' comfort is affected by drivetrain vibrations and other factors. In most cases, the conception of a heavy truck drivetrain contains main and second transmission. These transmissions are connected by a cardan shaft. Dominant vibrations of the drivetrain can be expected at engine speed [1], [2]. Another influencing factor of drivetrain vibration are vibrations generating during operation of gear pair. These tooth meshing frequencies can be defined as a product of the rotating speed and number of teeth. This relation cannot be applied to planetary gears, because planet gear is revolving around a central or sun gear, i.e., revolve around the fixed axle of the central gear [3], [4]. Next, drivetrain vibrations are affected by a cardan shaft, which contains two Hook's joints. During rotation of the Hook joint, there is a nonuniformity of motion transmission, for example, evidence of nonuniformity can be found at [5], [6], [7] or catalogues of some manufacturers. According to [8], nonuniformity can be eliminated by using same deflection angles of the Hook joint. In some applications, it is very difficult to provide this condition. Installation dimensions between main and second transmission and suspension of the transmissions have an important role in this problem. Another parameter which affects the influence of the cardan shaft on vibration is efficiency of the Hook joint. Efficiency of the Hook joint depends on these parameters [9], [10]:

- Diameter of the shaft $-d$

- Distance between the bearings of the cross $-D$

- Friction coefficient $-f$

- Angle between output and input shaft (deflection angle) - $\beta$ 
The efficiency also depends on the rotating speed and manufacturing accuracy, see [11], [12]. Influence of inertial masses is described in [13]. Another aspect of this issue is the suspension of the transmissions and engine. Based on the past measurements, the attention was devoted to transmission suspension.

\section{Cardan shaft angles and nonuniformity}

The occurrence of the non-uniformity is conditioned by a non-zero angle between the shafts. The relationship between angle rotation of drive part on angle rotation of driven (intermediate) part is described by equation (1). It is important to mention here, that a second equation exists (2), where initial condition (initial point) is shifted by $\frac{\pi}{2}[14]$. Calculations in this paper using equation (1).

$$
\begin{gathered}
\tan \left(\alpha_{1}\right)=\tan \left(\alpha_{2}\right) \cdot \cos (\beta) \\
\tan \left(\theta_{1}\right)=\frac{\tan \left(\theta_{2}\right)}{\cos (\beta)}
\end{gathered}
$$

where $\alpha_{1}$ - rotational angle of drive part, $\alpha_{2}$ - rotational angle of driven part, $\theta_{1}$ - rotational angle of drive part (complementary angle for $\left.\alpha_{1}\right), \theta_{2}$ - rotational angle of drive part (complementary angle for $\alpha_{2}$ ), $\beta$-deflection angle.

By expressing $\alpha_{2}$ from equation (1) and subsequent derivation by time, we can obtain mathematical model for angular velocity and acceleration of driven part, see equation (3)Chyba! Nenašiel sa žiaden zdroj odkazov., (4):

$$
\begin{gathered}
\omega_{2}=\dot{\alpha_{2}}=\frac{\omega_{1} \cdot \cos (\beta)}{\cos ^{2}\left(\alpha_{1}\right) \cdot \cos ^{2}(\beta)+\sin ^{2}\left(\alpha_{1}\right)} \\
\varepsilon_{2}=\ddot{\alpha_{2}}=\frac{\varepsilon_{1} \cdot\left[\tan ^{2}\left(\alpha_{1}\right)+1\right]}{\cos (\beta) \cdot\left[\frac{\tan ^{2}\left(\alpha_{2}\right)}{\cos ^{2}(\beta)}+1\right]}+\frac{2 \omega_{1}^{2} \tan \left(\alpha_{1}\right) \cdot\left[\tan ^{2}\left(\alpha_{2}\right)+1\right]}{\cos (\beta) \cdot\left[\frac{\tan ^{2}\left(\alpha_{2}\right)}{\cos ^{2}(\beta)}+1\right]}-\frac{2 \omega_{1}^{2} \tan \left(\alpha_{1}\right) \cdot\left[\tan ^{2}\left(\alpha_{2}\right)+1\right]^{2}}{\cos ^{3}(\beta) \cdot\left[\frac{\tan ^{2}\left(\alpha_{2}\right)}{\cos ^{2}(\beta)}+1\right]}
\end{gathered}
$$

where $\omega_{2}$ - angular velocity of driven part, $\omega_{1}$ - angular velocity of drive part (assumed constant in time), $\varepsilon_{2}$ - angular acceleration of driven part, $\varepsilon_{1}$ - angular acceleration of drive part (if $\omega_{1}$ is a constant $\varepsilon_{1}=0 \frac{\mathrm{rad}}{\mathrm{s}^{2}}$ )

Fig. 1 and Fig. 2 shows time course of the angular velocity $\omega_{2}$ and angular acceleration $\varepsilon_{2}$ of driven part. The dashed line shows time course obtained by using equation (2).

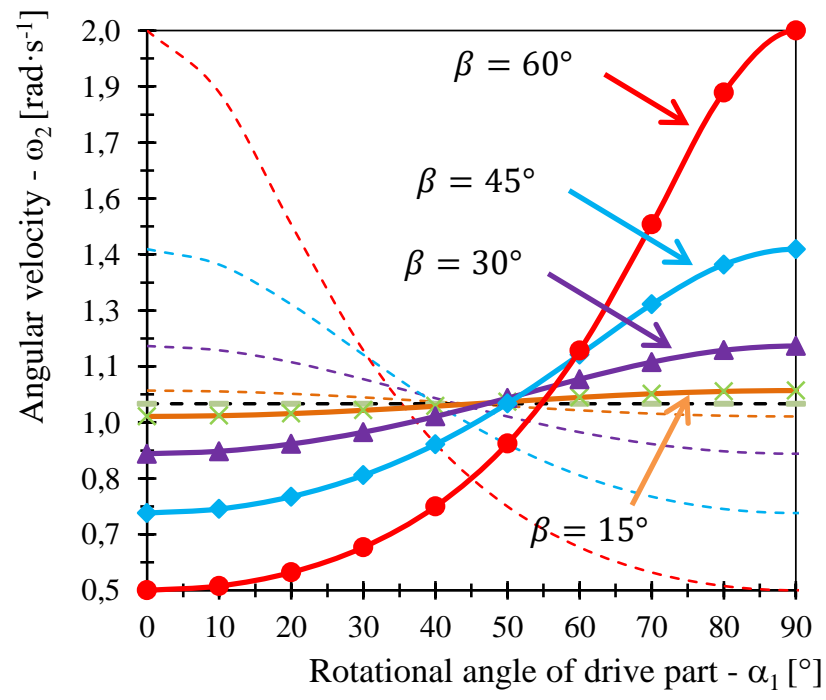

Fig. 1 Angular velocity $\omega_{2}$ in dependence on rotational angle $\alpha_{1}$ 


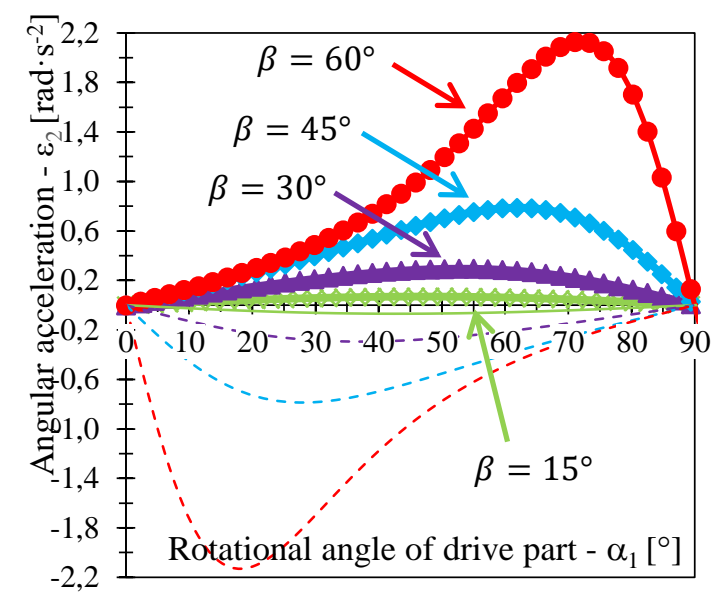

Fig. 2 Angular acceleration $\omega_{2}$ in dependence on rotational angle $\alpha_{1}$

From Fig. 1 and Fig. 2 we can see that the deflection angle $\beta$ has a big impact on the time course of angular velocity and acceleration. Nonuniformity is defined as the function of the maximal and minimal angular velocity of driven part and angular velocity of drive part:

$$
U=\frac{\omega_{\max }-\omega_{\min }}{\omega_{1}}=\tan (\beta) \cdot \sin (\beta)
$$

where $\omega_{\max }-\max$. angular velocity from time course, $\omega_{\min }-$ min. angular velocity from time course, $\omega_{1}$ - angular velocity on drive part.

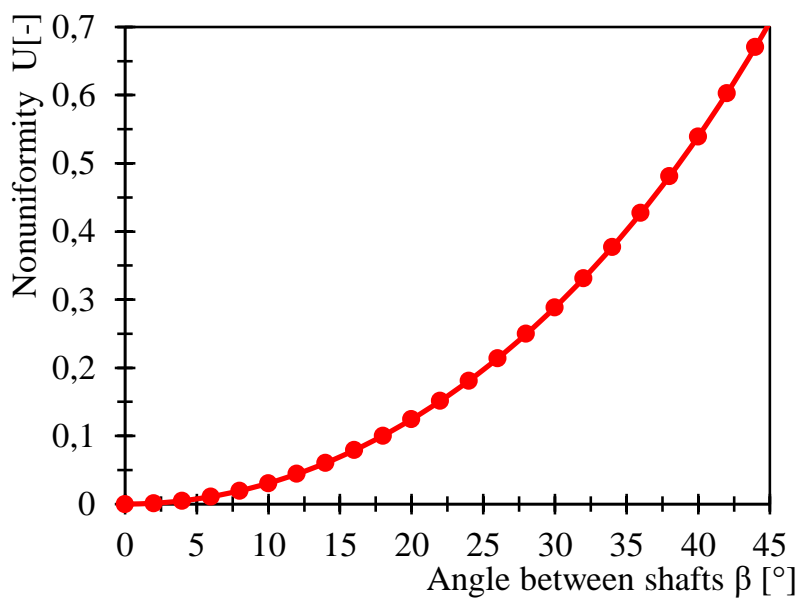

Fig. 3 Nonuniformity of Hook's joint

From Fig. 3, deflection angle significantly affects nonuniformity and time course of the angular velocity and acceleration. Torque on the shafts is a function of the angular velocity and it is affected by deflection angle as well. But the deflection angle is dependent on installation dimensions of the drivetrain. In this case on the horizontal and vertical position of the main and second transmission. Cardan shaft condition is shown on Fig. 4.

If $\mathrm{Z}$ or $\mathrm{V}$ arrangement of cardan shaft are assumed, where angles between drive and intermediate part and driven part are the same, rotational velocities of drive and driven part are same as well. In this application the angles are not the same. This causes non-constant rotational velocity on driven part. If the angular velocity is non-constant, then torque is nonconstant as well. This causes time varying loads on the driven part housing. For this reason, the relationship was derived. The equation (7) describes course of $\beta_{2}$ in dependence on installation dimensions and $\beta_{1}$ as a function of $\beta_{2}$. Equations (7), (6) were used for the characteristic below. 


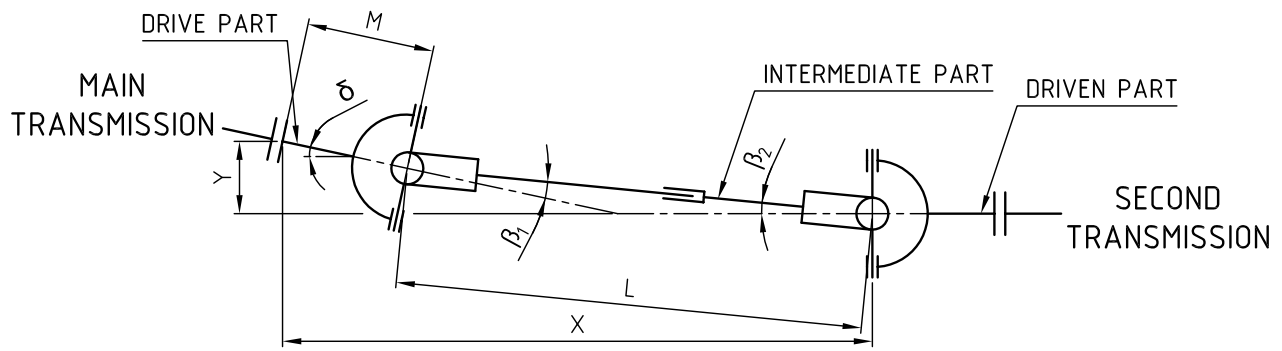

Fig. 4 Cardan shaft condition

$$
\beta_{2}=\operatorname{arcos}\left\{\frac{\left[\frac{Y-M \cdot \sin (\delta)}{\sin (\delta)}\right]^{2}-\left[X-M \cdot \cos (\delta)-\frac{Y-M \cdot \sin (\delta)}{\sin (\delta)} \cdot \cos (\delta)\right]^{2}-L^{2}}{-2 \cdot\left[X-M \cdot \cos (\delta)-\frac{Y-M \cdot \sin (\delta)}{\sin (\delta)} \cdot \cos (\delta)\right] \cdot L}\right\}
$$

where $M, L$-dimension given by the manufacturer, $X, Y$ - dimension given by the connected transmissions.

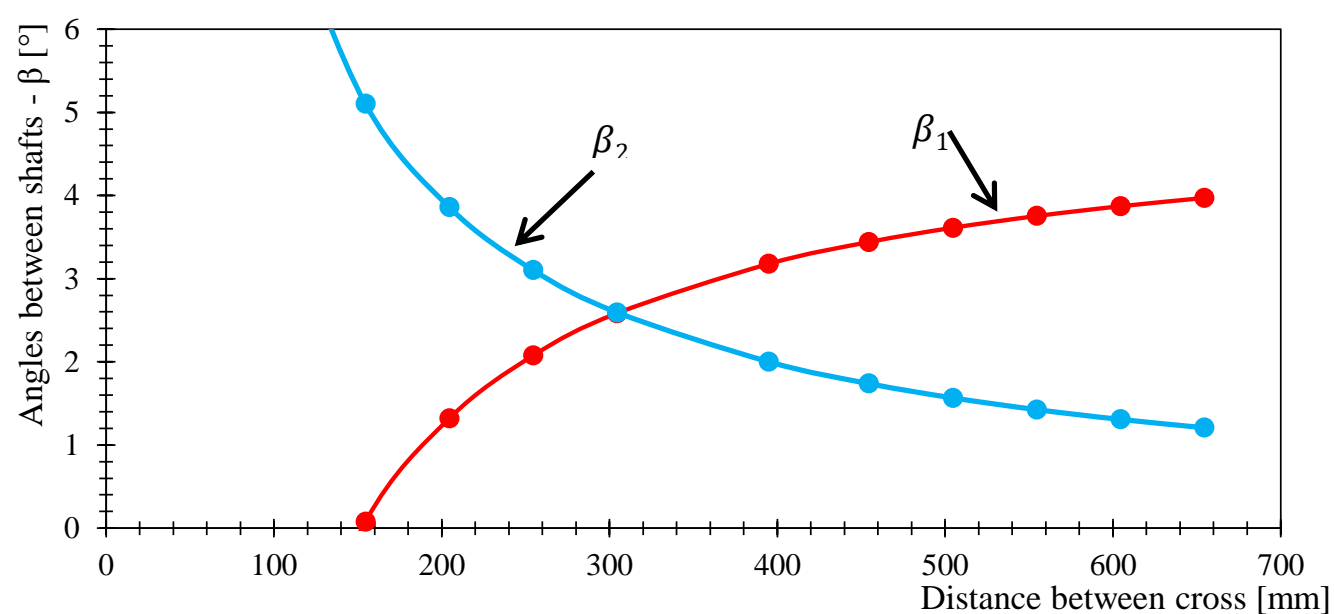

Fig. 5 Dependence of the deflection angles $\beta_{1}$ and $\beta_{2}$ on the dimensions between cross joints for $\delta=5,2^{\circ}$

From Fig. 5 it is evident that deflection angles are dependent on the length of the cardan shaft. It can be assumed that the difference between angles $\beta_{1}$ and $\beta_{2}$ rises with higher length. It is necessary to know that characteristic in Fig. 5 cannot be applied to all situations, because calculation depends on many variables (especially $M, L, X, Y$ ). The better way is to use equations (7), (1) and evaluate characteristic similar to Fig. 5 for solved application. It must be considered that due to compliance of the transmission mounting the size of the angles may be other than theoretical.

As seen above, there is description of the influence of the angle $\beta$ on a time course of the angular velocity and acceleration. Simultaneously, angle $\beta$ is influenced by the installation dimensions of the drive train, but these variables also influence the next indicator of the vibration's behaviour - modal properties of the cardan shaft. For this reason, the modal analysis was made. The intention is to maintain the dimension of drive and driven part of cardan shaft (diameters, sizes) and changing the length of intermediate part. It means that only the length between cross joints is changing. For higher accuracy of calculation, it was necessary to do exact housing simulation of drive part and driven part. The scheme of computational model can be seen in Fig. 6. Ball bearing on the drive shaft is used in this application. Tapered roller bearing is used 
on the driven shaft. These bearings were replaced by revolute joints. For ball bearing there was rotation around all axes allowed because ball bearings permitted some rotation. In the case of the tapered roller bearing there was disabled rotation. In this application tapered roller bearings have some internal clearance. For this reason, translation in axial direction was enabled.

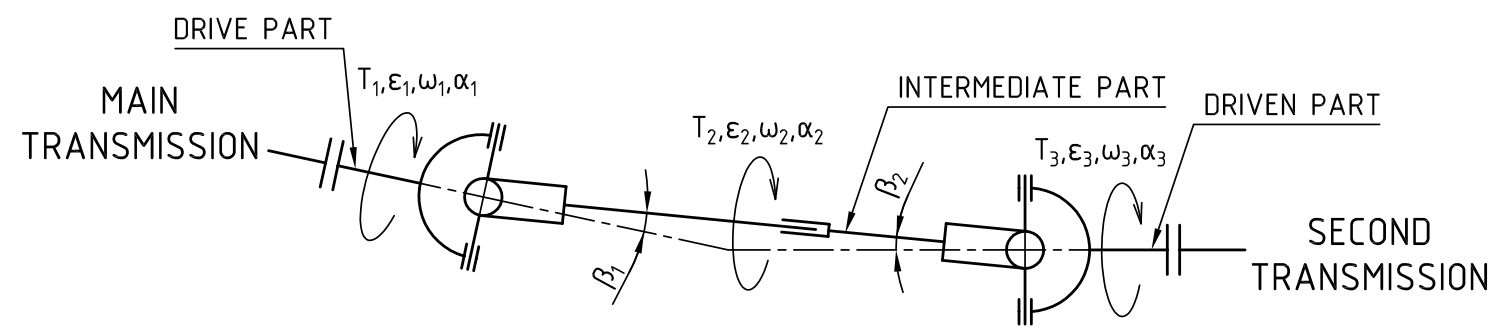

Fig. 6 Scheme of the computational model of cardan shaft for modal analysis in FEM software

There is dependence of cardan shaft length on first eigenfrequency in Fig. 7. From this figure it is obvious that the first eigen frequency is smaller with bigger length. This is caused by approaching of the first eigen frequency to operating frequency and then increasing vibration generation by rotating of cardan shaft.

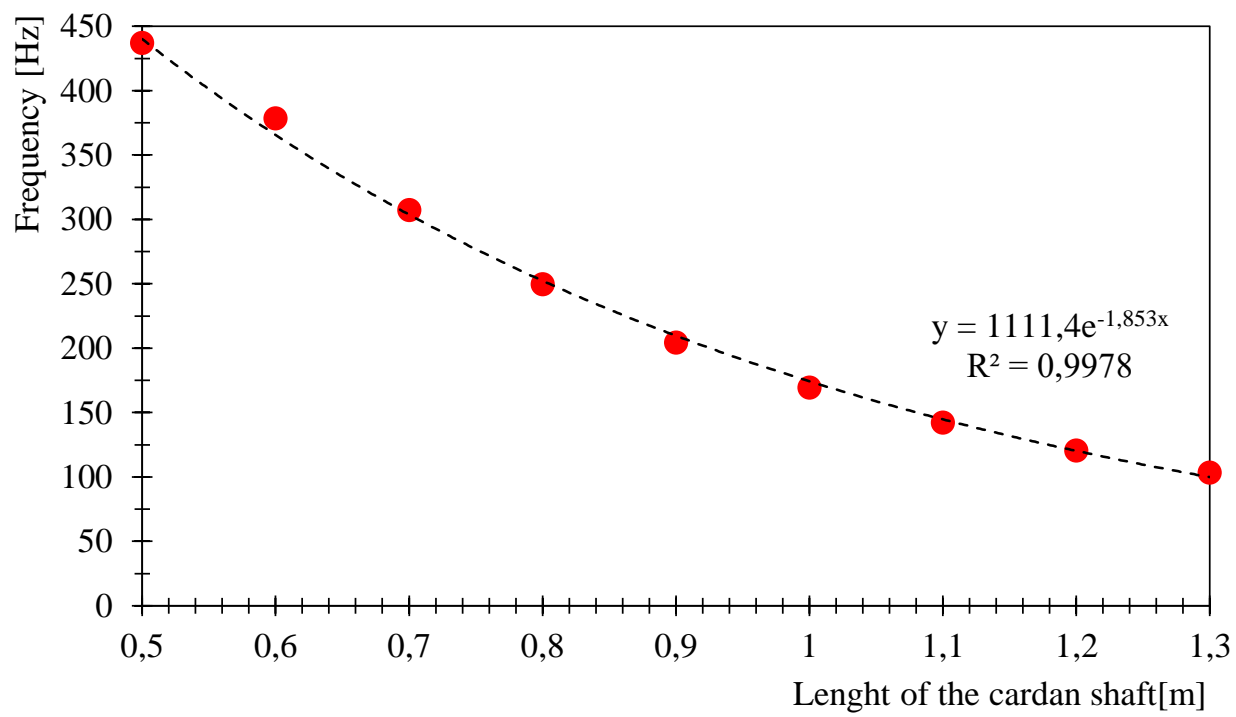

Fig. 7 Dependence of the cardan shaft length on first eigen frequency

Fig. 8 and Fig. 9 show direction deformation at first and second eigen frequency. From Fig. 9 it is visible that the least rigid place is in the cross joint area.
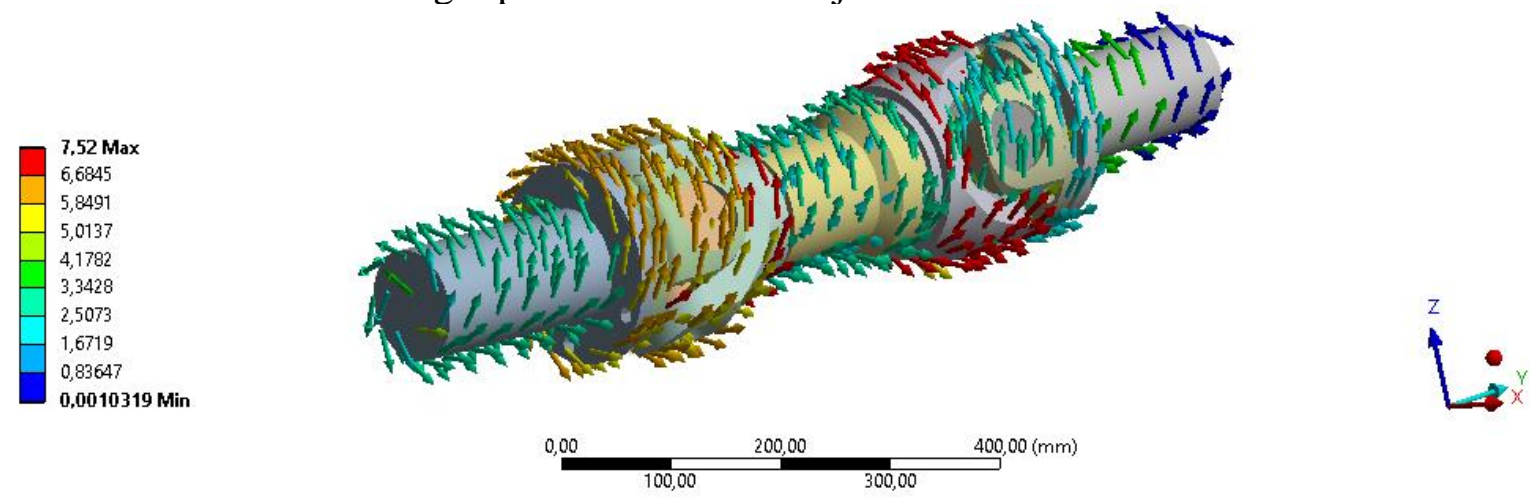

Fig. 8 Direction of deformation at first eigenfrequency 


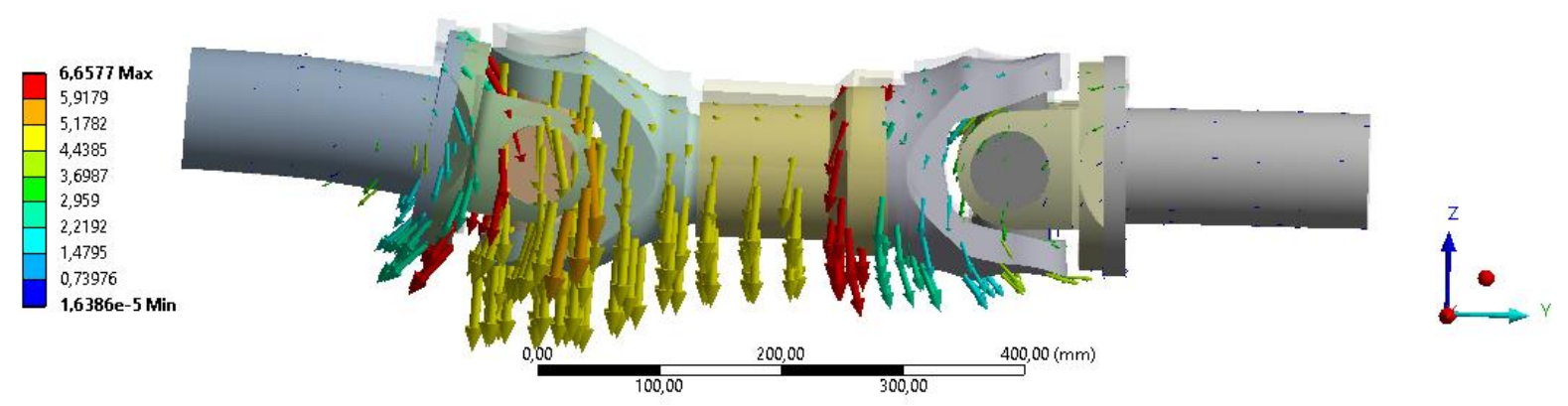

Fig. 9 Direction of deformation at second eigenfrequency

To verify results obtained by modal analysis in FEM software, experimental modal analysis on cardan shaft with length approximately $350 \mathrm{~mm}$ (between cross joints) was made. The principle of the experiment was similar to [15]. This analysis proved, that error of the FEM is minimal, see Fig. 10. Ideally, the points should go through the function $y=x$, because this curve is also quadrant axis and forms angle $45^{\circ}$ with $\mathrm{x}$ or $\mathrm{y}$ axis. Due to measurement error the points go through the curve which is tilted (red curve). The red curve has no angle $45^{\circ}$ between curve and $x$ or $y$ axis. It is caused by measurement error such as movement of the cardan shaft during the experiment. Theoretical calculation does not take damping and other material properties in FEM analysis into account. Afterwards, the modal analysis for the model was conducted, which is prestressed by operating torque.

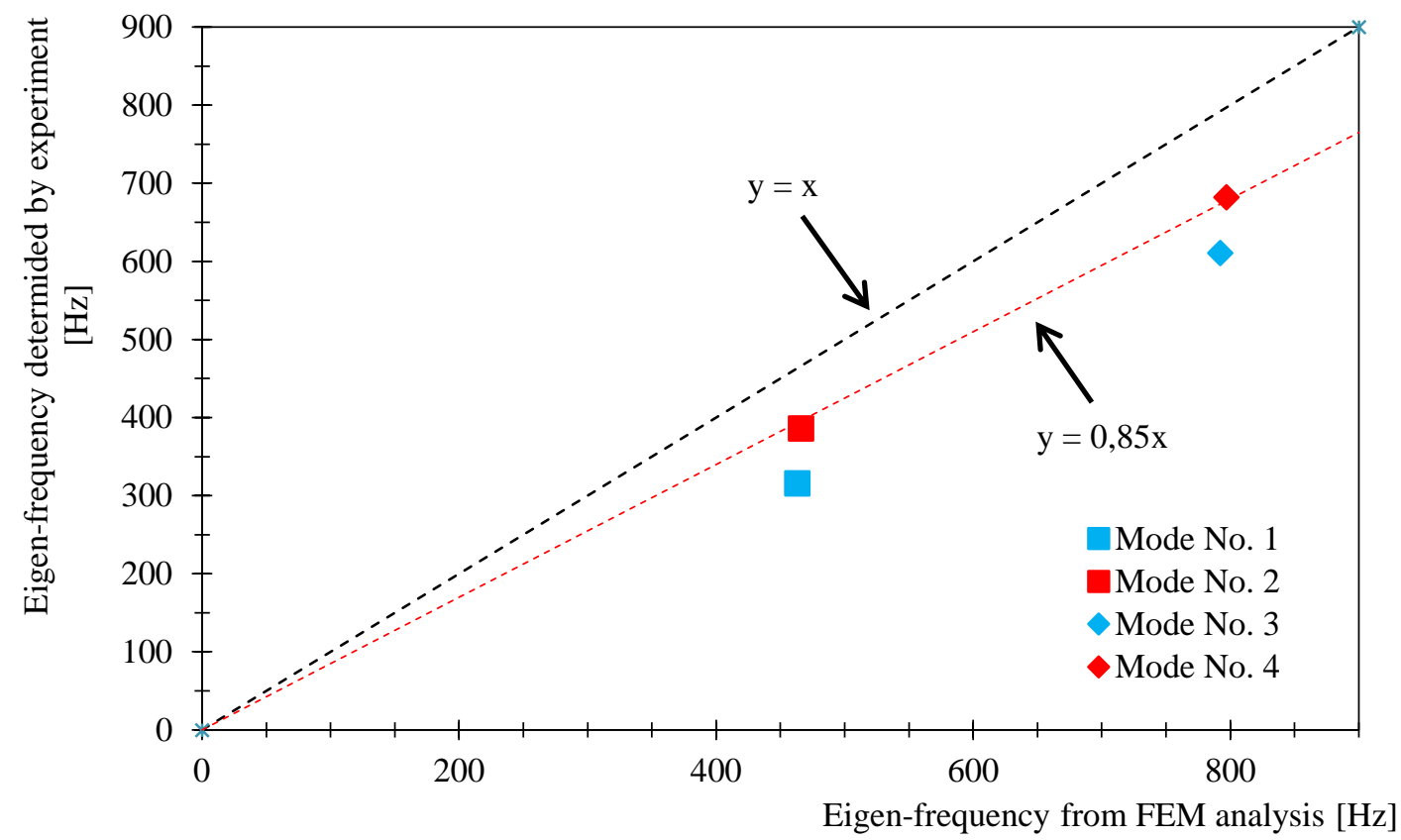

Fig. 10 Comparison results from experiment and FEM analysis

\section{Measurement and evaluating vibrations}

Measurements of vibrations were made during the operation at different engine speeds. Evaluations contain values measured at engine speed $1200 \mathrm{~min}^{-1}$ and $1700 \mathrm{~min}^{-1}$ at different places. To evaluate measured data Fourier transform was chosen. Frequency spectrums obtained at engine speed $1200 \mathrm{~min}^{-1}$ and $1700 \mathrm{~min}^{-1}$ (rotating speed of cardan shaft is $3,65 s^{-1}$ and 6,1 $s^{-1}$ ) are mentioned here from large number of measured frequency spectrums. Fig. and Fig. show position of the sensors. 


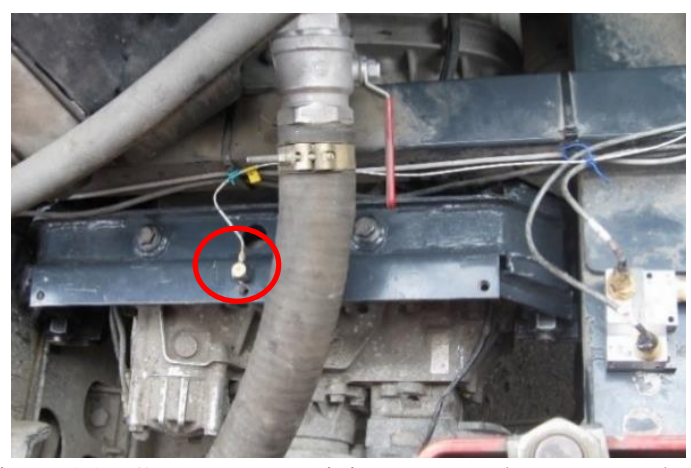

Fig. 11 Sensor position on the gear box bracket

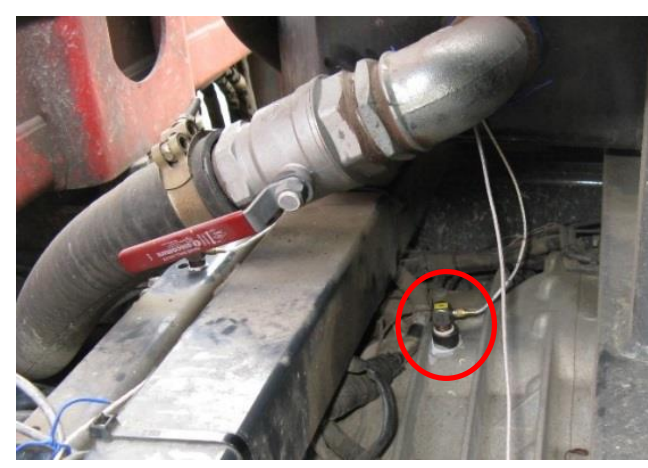

Fig. 12 Sensor position on the gear box

Figures below show the types of the gearbox brackets, one using square suspension bushing and second using cylindrical suspension bushing.

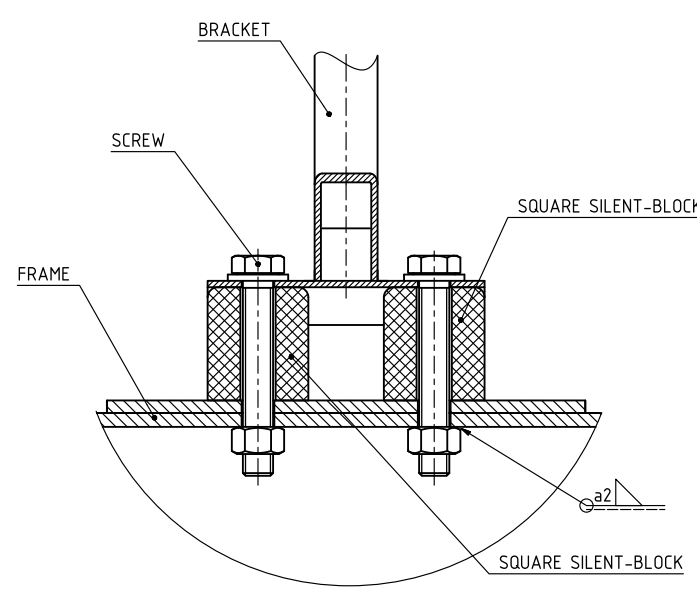

Fig. 13 Bracket with square suspension bushing

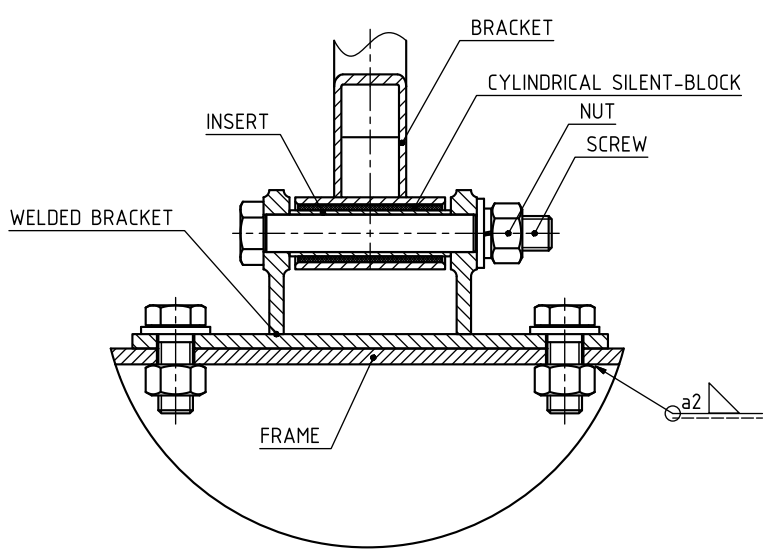

Fig. 14 Bracket with cylindrical suspension bushing

From Fig. 15 and Fig. 16 it is visible that the use of square suspension bushing causes higher vibrations than cylindrical suspension bushing. Frequencies of some parts of the systems are marked in Fig. 15 and Fig. 16. Special attention was dedicated to tooth frequency of spur gears in second transmission and to planetary gearbox, which is a part of the main transmission. According to experience of university staff, the planetary gearbox is a system which is very inclinable to vibrations. From this reason frequency of the planetary gearbox was calculated and compared with frequency spectrums. Vibration of spur gears [4] is caused by irregularities on the periphery of the spur gear, misalignment, deformation of the tooth under load and at variable stiffness of the teeth. The situation at the planetary gear is more complex because the planet gears are revolving about central gear axis. Then the planet gear is mounted to the movable arm which itself may rotate relatively to the central gear. To evaluate rotational frequencies of the parts of the planetary gearbox it is necessary to know the number of teeth of the planet gear, central gear, and outer ring gear and numbers of planet gears [3].

As the result, we can see that vibrations on these frequencies are very low from Fig. 15. The main vibrations occur at the cardan shaft and engine frequency. Higher frequency vibrations are present on second transmission spur gears frequency. This frequency is $>100 \mathrm{~Hz}$ and it is invisible in spectrum, which is limited to $100 \mathrm{~Hz}$, because of size and in this case, we focus on vibrations at low frequencies. Fig. 16 shows vibrations analysis at higher engine speed. At this 
case teeth frequency was evaluated too. From Fig. 16 it is visible that engine frequency and frequency of any tooth of central spur gear are the same. There is frequency of any tooth of outer ring with planet gear in a proximity. This is a negative phenomenon. From Fig. 15 and Fig. 16 it is obvious that while we are using cylindrical suspension bushing, vibrations at second harmonic frequency of the cardan shaft are eliminated. The disadvantage of this phenomena is that vibrations at engine frequency are higher. These vibrations occur at higher frequency than the second harmonic frequency of cardan shaft. Shifting dominant vibrations to higher frequency has negative impact on lifetime of the frame and other parts.

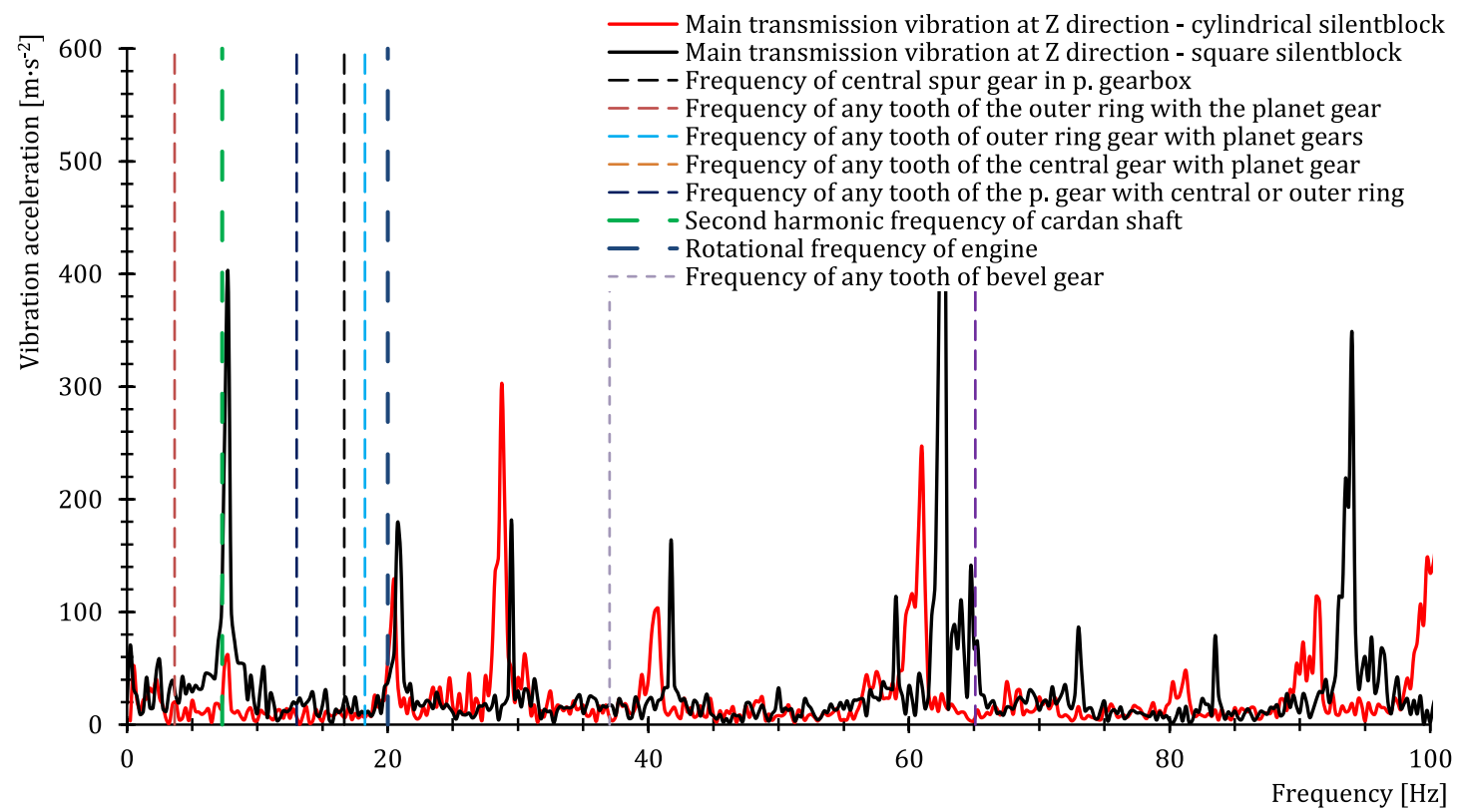

Fig. 15 Frequency spectrum (fast Fourier transform) on gearbox (according to Fig. ) - engine speed $1200 \mathrm{~min}^{-1}$ [red line - using cylindrical suspension bushing, black line - using square suspension bushing

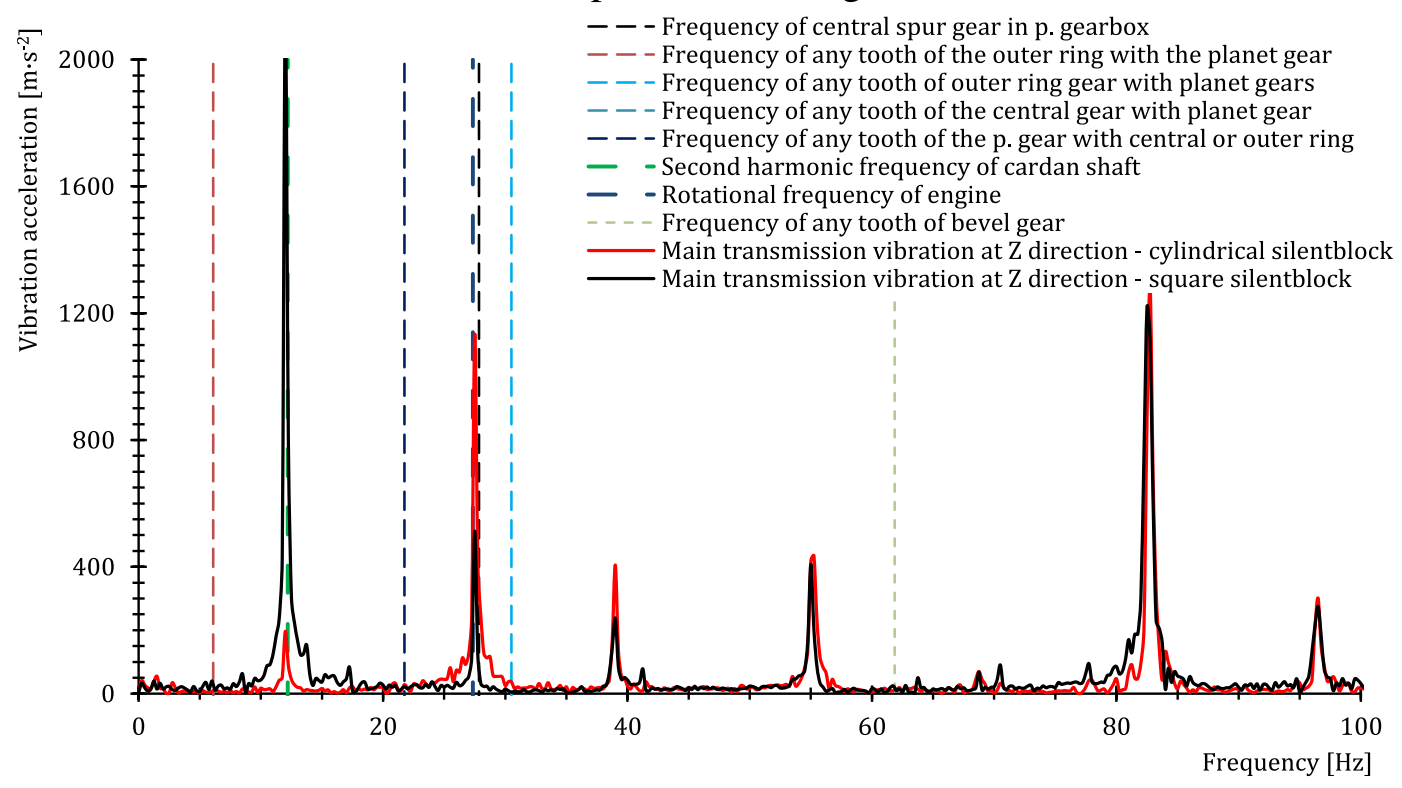

Fig. 11 Frequency spectrum (fast Fourier transform) on gearbox (according to Fig. ) engine speed $1700 \mathrm{~min}^{-1}$ [red line - using cylindrical suspension bushing, black line - using square suspension bushing] 


\section{CONCLUSION}

This article describes solution procedure and it scrutinizes vibrations causes. The first part of this article is dedicated to description of the kinematics of the Hook's joint. This chapter is focused on nonuniformity of Hook's joint. Nonuniformity is influenced by deflection angle $\beta$ and have negative impact on the time course of the angular velocity and acceleration. The deflection angle $\beta$ depends on the installation dimensions of the drivetrain. For this reason, the dependency of the deflection angle and dimension between cross were derived. This characteristic and mathematical formula can be used by drivetrain designers and in on-line catalogues of manufactures for design calculations. In the case of on-line catalogues, it is necessary to do a dimension database of offered cardan shafts (mean dimension $M, L$ ). Also, thanks to this formula, further, effect of cardan shaft length was investigated. It is evident, that angle between shafts is changing with distance between Hook's joints, but modal analysis proved, that first eigen frequency going down with length and is approaching to operating frequencies. Numerical analysis was verified by the experimental modal analysis and it is an evidence of the small difference between numerical and experimental results. Modal analysis also proved, that the least rigid place at cardan shaft is cross in Hook's joint. Based on this, it is possible to assume that the reduced length method, see page 297 in [16], is not accurate enough in this case. Measured vibrations were evaluated in the last part of this article. These vibrations were measured at different engine speeds and in different places. This article shows vibrations measured at gearbox bracket and on the gearbox. In this paper, frequency spectrums are listed where various frequencies are indicated (frequency of cardan shaft, engine frequency, teeth frequency of spur gears at second transmission and frequency of gears at planetary gearbox which are a part of the main transmission). Simultaneously two kinds of suspension bushing (square and cylindrical) were compared. It follows the measurements using the cylindrical suspension bushing and eliminates vibrations at second harmonic frequency of cardan shaft. On the other side it excites vibrations at higher frequencies (especially engine frequency). This trend is noticeable at every measured place. It indicates that the cylindrical suspension bushing causes stiffer joint of main transmission with the frame.

\section{ACKNOWLEDGEMENT}

This article was developed within the project SP2021/31- ,Experimentální a výpočtové metody dimenzování strojních součástí 2021 “

\section{REFERENCES}

[1] Chlebo, O., Onderová, I., Čačko, V., Šooš, V. "Evaluation of bearing operating efficiency by vibration", Lepotech 2020, Brno: Brno University of Technology, 2020. ISBN 97880-214-5871-0

[2] Jahanbakshi, A., Ghamari, B., Heidarbeigi, K. "Vibrations analysis of combine harvester seat in time and frequency domain", Journal of Mechanical Engineering and Sciences (JMES) 14 (1), pp. 6251 - 6258, 2020. DOI: 10.15282/jmes.14.1.2020.04.0489

[3] Tůma, J. "Vehicle Gearbox Noise and Vibration: Measurement Signal Analysis, Signal Processing and Noise Reductioin Measures". Wiley, 2014. ISBN 978-1-118-35941-9

[4] Tůma, J. “Zpracování signálů získaných z mechanických systémů užitím FFT”, Praha: Sdělovací technika, 1997. ISBN 80-901936-1-7.

[5] An, K., Wang, W. "Transmission performance and fault analysis of a vehicle universal joint". Advances in Mechanical Engineering 9 (5), pp. 1 - 10, 2017. DOI: $10.1177 / 1687814017707478$ 
[6] Vesali, F., Ali Rezvani, M., Kashfi, M. "Dynamics of universal joints, its failures and some propositions for practically improving its performance and life expectancy", Journal of Mechanical Science and Technology 26 (8), pp. 2439 - 2449, 2012. DOI: $10.1007 / \mathrm{s} 12206-012-0622-1$

[7] Brát, V., Lederer, P., Stejskal, S. "Kinematika”, České vysoké učení technické v Praze, Praha, 1986.

[8] Vlk, F. "Převodová ústrojí motorových vozidel”, 2. vyd., Brno: František Vlk, 2003. ISBN 80-239-0025-0

[9] Němec, A., Boháček, F., Bureš, V. “Č́asti strojů III: Hřídele, ložiska a spojky”, Praha, Vysoké učení technické v Brně, Fakulta strojní, Vysokoškolská skripta, 1964.

[10] Biancolini, M. E., Brutti, C., Pennestri, E., Valentini, P.P. "Dynamic, Mechanical Efficiency and Fatigue Analysis of the Double Cardan Homokinetic Joint", International Journal of Vehicle Design - INT J VEH DES 32 (01), 2003. DOI: 10.1504/IJVD.2003.003559

[11] Pennestri, E., Vita, L. Valentini, P.P "KINEMATICS, DYNAMICS AND MECHANICAL EFFICIENCY OF A CARDAN JOINT WITH MANUFACTURING TOLERANCES [online]. [cit. 2019-07-08]. Available at: https://www.researchgate.net/publication/289202304_Kinematics_Dynamics_and_mech anical_Efficiency_of_a_Cardan_Joint_with_Manufacturing_Tolerances, [Accessed: 29 September 2021].

[12] Pennestri, E., Vita, L. Valentini, P.P "KINEMATICS, DYNAMICS AND MECHANICAL EFFICIENCY OF A CARDAN JOINT WITH MANUFACTURING TOLERANCES - Part II", [online] Available at: https://www.google.com/url?sa=t\&rct=j\&q=\&esrc=s\&source=web\&cd=\&ved=2ahUK Ewid8Lb4z6PzAhWB_7sIHYT6BNsQFnoECAsQAQ\&url=http\%3A\%2F\%2Fciteseerx .ist.psu.edu\%2Fviewdoc\%2Fdownload\%3Fdoi\%3D10.1.1.638.5412\%26rep\%3Drep1\% 26type\%3Dpdf\&usg=AOvVaw3XN9-qlES3YqcEhCwZQ3Cy, [Accessed: 29 September 2021].

[13] Šalinić, S., Vranić, A., Nešić N., Tomović, A. "On the torque transmission by a CardanHooke joint", FME Transactions 45 (1), pp. 117 - 121, 2017. DOI: $10.5937 /$ fmet1701117S

[14] Struž, J. “Teze disertační práce - Analýza vibrací kardanové hřídele pohonu nákladního automobilu”, Ostrava,. Teze disertační práce, Vysoká škola báňská - Technická univerzita Ostrava, 2020.

[15] Úradníček, J., Musil, M., Bachratý, M. "Frequency Response Function Measurement on Simplified Disc Brake Model", Strojnícky časopis - Journal of Mechanical Engineering 68 (3), pp. 225 - 230, 2018. DOI: 10.2478/scjme-2018-0036

[16] 'Naftové motory čtyřdobé: určeno pro vývojové a projekční pracovníky, konstruktéry naftových motorů i technický dorost vysokých i vyšších technických škol”, 2. vyd. Praha: Státní nakladatelství technické literatury, Řada strojírenské literatury, 1964. 